\title{
Circulations and therapeutic quests in mental health in Senegal
}

Véronique Petit

\section{(2) OpenEdition}

Journals

Electronic version

URL: http://journals.openedition.org/rfst/81

DOI: $10.4000 /$ rfst.811

ISSN: 2492-3672

Publisher

Espaces et SOciétés (UMR 6590)

\section{Electronic reference}

Véronique Petit, "Circulations and therapeutic quests in mental health in Senegal", Revue francophone sur la santé et les territoires [Online], Healthy circulation: products, knowledge, people on the move, Online since 16 December 2019, connection on 06 April 2021. URL: http://journals.openedition.org/ rfst/811 ; DOI: https://doi.org/10.4000/rfst.811

This text was automatically generated on 6 April 2021.

\section{(c) (i) (2) (2)}

La Revue francophone sur la santé et les territoires est mise à disposition selon les termes de la Licence Creative Commons Attribution - Pas d'Utilisation Commerciale - Partage dans les Mêmes Conditions 4.0 International. 


\title{
Circulations and therapeutic quests in mental health in Senegal
}

\author{
Véronique Petit
}

1 In this article we have chosen to focus on the circulations related to therapeutic mental health quests in the countries of the South through the example of Senegal. Mental health is not one of the priority health programs supported by the Global Fund, few countries in the South have specific mental health policies and programs, and it is not the subject of strong political and financial mobilization. According to WHO estimates, the majority of people with severe mental disorders are untreated and have diminished rights. With more accurate measurement of the disease burden, mental health has been included in the objectives of sustainable development and in overall public health. It is, in addition, a development issue given its social and economic costs to countries and families. Nevertheless, research on mental health in sub-Saharan Africa, whatever the discipline, is still too rare.

2 Senegal was chosen for this research for two reasons: first, since French colonization, it has had an internationally recognized psychiatric range of services, and second Senegalese society is characterized by international migration and significant circular mobility, which anchors it in processes of globalization. The various circulations that contribute to structuring therapeutic pathways that are often long and chaotic before accessing psychiatric care are described mainly on the basis of anthropological data collected from people experiencing mental illness, either alone or supported by "their accompanying person(s)". These data are based on field surveys conducted in several psychiatric services and mental health centers throughout the country. Consultations were followed in agreement with the medical and administrative authorities, observations and interviews were carried out with healers, sick people and their "companions" in order to understand the therapeutic pathways, the management of the disease and drug treatments as well as the representations of psychological disorders in a context of stigmatization of madness. The investigation continued beyond the walls of the psychiatric institution with healers, marabouts and representatives of mystical medicine in order to take into account the plurality of 
therapeutic remedies and the movements that take place at local, national and even transnational levels. The interviews were conducted either in French or Wolof (translated by an investigator trained in health anthropology).

3 The circulation of actors, products and practices is analyzed at different spatial and social scales and interpreted in relation to different explanatory and contextual factors. In the Senegalese health care system, mental health is not included in the primary care system. Map 1 reveals an insufficient supply of psychiatric care and deep inequalities between the West (the capital Dakar region) and the East of the country, as with other medical disciplines that are under-staffed and under-resourced. Sick people who consult in health centers or dispensaries are referred to the psychiatric unit in the health region where they reside or to the private sector if they have sufficient resources. Nevertheless, the pyramidal medical hierarchy is not always respected because it goes against the social logic of patients and their families who wish to consult in the greatest secrecy because of the social representations of madness. Therapeutic pathways therefore depend in part on accessibility and the additional costs of distance.

4 The accounts of the therapeutic pathways reveal that psychiatry is often considered the ultimate solution in the event of an acute crisis, particularly in rural areas. It is a solution sometimes forced by the neighborhood or the authorities in the face of symptoms that cause fear and disapproval. Given the context of stigmatization and reluctance towards psychiatric institutions, families are experimenting with other therapeutic alternatives with healers and marabouts who may specialize in the treatment of madness or in a so-called "mystical" medicine that is rooted in Islam. This is also due to certain popular beliefs that insanity is not curable, which hinders adherence to psychiatric treatment. This leads to the interruption of treatment as soon as the patient is perceived to be doing better. The narratives of the interviewees also reveal self-medication practices that aim to regulate the behavior of sick people in the family and social space of the community. It helps to limit medical and indirect costs related to accessibility, as many families do not have universal medical coverage or sufficient financial resources. It reveals the circulation and sometimes diverted use of medicines after a medical check-up. In conclusion, we observe that the question of the management of psychological disorders is similar to that of chronic diseases (adherence to treatment, representation of recovery). It is also part of a context where a plurality of actors are taking hold of a protean "psy" discourse within Senegalese society. 
Map 1. Distribution of mental health services in Senegal (2019)

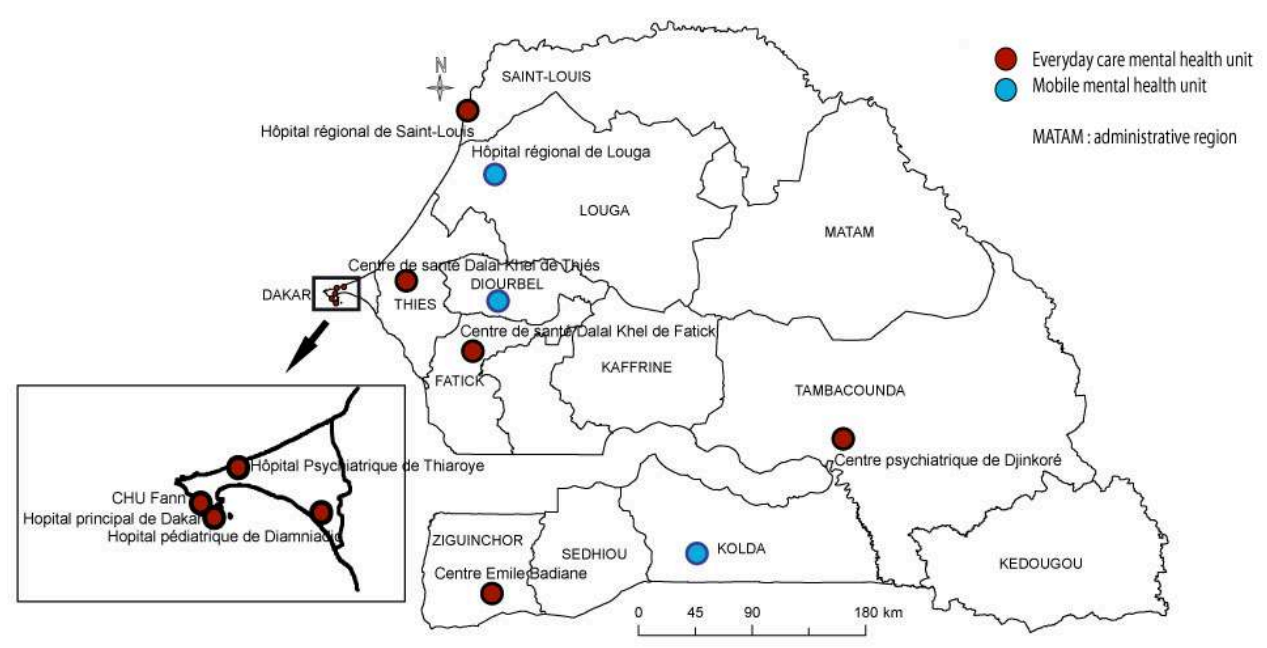

INDEX

Keywords: mental health, therapeutic quests

Geographical index: Senegal

\section{AUTHOR}

\section{VÉRONIQUE PETIT}

Socio-démographe, Professeur Université Paris Descartes, CEPED/IRD 